\title{
Knowledge, attitude and practice related to reproductive health among female adolescents
}

\author{
Sharifa M. Gaferi ${ }^{1}$, Manal F. Al-Harbi*1, Sahar M. Yakout ${ }^{2}$, Aziza T. Soliman ${ }^{1}$ \\ ${ }^{1}$ Department of Maternity and Child Health Nursing, College of Nursing, King Saud University, Riyadh, Saudi Arabia \\ ${ }^{2}$ Maternity and Gynecologic Nursing Department, College of Nursing, Alexandria University, Alexandria, Egypt
}

Received: January 21, 2018

Accepted: February 22, 2018

Online Published: March 26, 2018

DOI: $10.5430 /$ jnep.v8n8p53

URL: https://doi.org/10.5430/jnep.v8n8p53

\begin{abstract}
Objective: Reproductive health $(\mathrm{RH})$ is a crucial aspect of general health; it is a reflection of health during adolescence and adulthood. The period of adolescence in females is a period of physical and psychological preparation for safe motherhood. As direct reproducers, adolescent girls' health influences not only their own health but also the health of the future generation. This study aimed to assess knowledge, hygiene practices during menses, and attitudes of female adolescents in Riyadh female secondary schools regarding $\mathrm{RH}$ aspects.

Methods: A quantitative descriptive cross-sectional design was used for this study conducted on 350 female students selected from governmental secondary schools in Riyadh using multistage random sample type. Two tools were used for data collection in the current study: a self-administered questionnaire and an Attitudinal Assessment scale.

Results: The findings showed that more than two-thirds $(66.3 \%)$ of the participants had inaccurate knowledge, while about one-third $(33.7 \%)$ of them had correct knowledge regarding $\mathrm{RH}$. With respect to overall hygiene practices during menstruation, about $95.4 \%$ had correct menstruation hygiene practice, while only $4.6 \%$ had incorrect practices. The majority $(88.3 \%)$ of students had positive attitudes regarding $\mathrm{RH}$, while only $11.7 \%$ had negative attitudes. Mothers are a vital source of information regarding $\mathrm{RH}$.

Conclusions: The present study concluded that female adolescents had unsatisfactory knowledge, inadequate hygiene practices, and positive attitudes toward RH. It is recommended to improve adolescents' knowledge regarding RH issues and involve their parents and teachers to provide appropriate education related to RH issues.
\end{abstract}

Key Words: Knowledge, Adolescent, Reproductive health, Practice, Attitude

\section{INTRODUCTION}

The World Health Organization (WHO, 2017) identifies adolescence as the period of human growth and development that occurs after childhood and before adulthood, from 10 to 19 years of age. ${ }^{[1]}$ This period of adolescence is further categorized into three stages, namely early adolescence (10 to 13 years), mid-adolescence (14 to 15 years), and late adolescence (14 to 15 years). ${ }^{[2]}$ The period of adolescence for a girl is a period of physical and psychological preparation for safe motherhood. ${ }^{[3]}$ Reproductive health (RH) covers all aspects of adolescent health. The WHO defines RH as "a state of complete physical, mental and social well-being, and not just the absence of disease or debility, in all circumstance relating to the reproductive system and its functions and processes." ${ }^{[4]}$ It is an important aspect of female adolescents' global health milestones. Menarche is one of these mile-

\footnotetext{
* Correspondence: Manal F. Al-Harbi; Email: drmanalalharbi@gmail.com; Address: Department of Maternity and Child Health Nursing, College of Nursing, King Saud University, Riyadh, Saudi Arabia.
}

Published by Sciedu Press 
stones. A female individual's RH status is greatly influenced by their perception to menarche during adolescence, beliefs and attitude regarding menstruation, and more importantly, the behavior during this period. ${ }^{[5]}$ Another aspect of the $\mathrm{RH}$ is the age of marriage. Early marriage is generally associated with early childbearing and high fertility, both of which are health risks for women and their children. ${ }^{[6]}$ In terms of family planning, adolescent girls globally are probably the most vulnerable group as they are the victims of early marriage and early and frequent childbearing, all of which lead to high morbidity and mortality. ${ }^{[7,8]}$ Controlling both the number and timing of births through utilization of contraception is associated with improved maternal and neonatal health outcomes. Reports from around the world reveal that many women suffer from illnesses and disabilities resulting from easily preventable pregnancies and childbirth-related complications. Family planning (FP) has been associated with positive health effects on children, mothers, and the entire family. ${ }^{[9-12]}$

In the new era of globalization, adolescents are exposed to unlimited information from numerous resources. Television, movies, music, magazines, and internet play a vital role in providing information on every topic, particularly RH. However, in many instances, the information provided is not accurate or culturally competent. While parents and schools should play a significant role in providing sex education, studies show that parents rarely talk in a timely and comprehensive manner to their children, and schools are limited in what they can teach. ${ }^{[13]}$ The hygiene-related practices in the adolescent period related to menstruation can have an effect on their health. The event of menarche may be associated with taboos and myths existing in our traditional society which has a negative implication for women's health, particularly their menstrual hygiene. ${ }^{[14]}$ Studies have shown that lack of knowledge about menstruation and lack of hygiene are likely to lead to STDs in adolescents. ${ }^{[15,16]}$ Therefore, accurate and adequate RH knowledge at this age is crucial for proper practices and behavior regarding $\mathrm{RH}$ for the future. ${ }^{[17]}$ A study was conducted by Al-Quaiz et al. (2013) to assess sexual health knowledge, attitudes, and resources among adolescent girls in public and private schools in Riyadh, SA; it was identified that $42 \%$ of students discuss RH topics with their friends, $15.8 \%$ with their parents, and $17 \%$ with their household servants. ${ }^{[18]}$ Adolescents often lack basic RH knowledge and behavior and are less comfortable accessing RH services than adults due to embarrassment or discomfort in discussing sensitive topics with their healthcare provider and less favorable attitudes toward the use of healthcare services and providers. ${ }^{[19]}$

\subsection{Statement of the problem}

In most of the MENA countries, sexual and reproductive health is socially and culturally sensitive issue. As a result, RH information and services do not reach the majority of adolescents, leading to misconceptions, confusion, and lack of awareness among this vulnerable group. Few countries such as Tunisia, Morocco, Yemen, Turkey, and Iran have begun to focus on youth sexual and reproductive issues using international policy frameworks to map out their approach. ${ }^{[13]}$

Research on youth sexuality in MENA countries is still in the early phase of establishing a baseline for information on knowledge, attitudes, and behaviors among diverse populations. There are some unpublished reports regarding the level of sexual education imparted through the schools in the Kingdom of Saudi Arabia (KSA), but no scientific, epidemiological survey on sexual health in KSA has been conducted among adolescent girls. ${ }^{[13]}$

\subsection{Significance of the study}

Adolescents represent great potential human resources for the overall development of a nation. Presently, almost 1 in 5 persons in the world is an adolescent, which is 1.2 billion people between the ages of 10 and 19 years, accounting for 17 percent of the global population. ${ }^{[19-21]}$ Currently, there is a low level of access to high-quality $\mathrm{RH}$ information and services, especially for adolescents. ${ }^{[22]}$ There is limited discussion of issues concerning RH in general, and specifically, in the MENA countries. ${ }^{[23]}$ In the past few years, the issues of RH have been increasingly perceived as a social problem; they have been emerging as a topic of increasing concern in both developed and developing countries. ${ }^{[24]}$ Therefore, focusing on adolescents' $\mathrm{RH}$ is both a challenge and an opportunity for healthcare providers. While adolescence generally is a healthy period of life, many adolescents are less informed, less experienced, and less comfortable accessing health services for RH than do adults. ${ }^{[19]}$ In this light, it is essential to investigate this matter in some areas of KSA to establish a baseline for information on knowledge, especially among secondary school adolescents. The Health Belief Model (HBM) was used as the conceptual framework for this study. The HBM is one of the most widely used conceptual frameworks for understanding health behaviors and is believed to lay the foundation of a study, which enables the researcher to identify what is known or unknown about the topic of interest in order to conduct research that adds to the body of knowledge. ${ }^{[25]}$ This study aimed to assess the knowledge, attitude, and practices of female adolescents regarding $\mathrm{RH}$ in Riyadh. 


\section{MethodS}

\subsection{Research design}

A quantitative descriptive cross-sectional design was used in this study.

\subsection{Setting}

The study was conducted at 6 governmental secondary schools representing the eight educational zones of the central Riyadh city.

\subsection{Population and sampling type}

Multistage sampling technique was used as follows:

Stage I: Riyadh city is divided into 5 sectors: north, south, east, west, and central of city. The governmental secondary schools for females in Middle of Riyadh city were selected randomly.

Stage II: Middle of Riyadh includes 8 areas, and there are a total of 12 governmental female secondary schools distributed in those 8 areas; six secondary schools were chosen by simple random sampling technique.

Stage III: From each grade, 58-59 students were selected systematically, and 350 female students who met the criteria were included in this study.

\subsection{Sample size}

Statistically, calculated sample size equals 350 female students from the total of 2,452 female students based on the last census for the Ministry of Education at the governmental secondary schools in the middle of Riyadh city (Saudi Arabia Ministry of Education Census, 2014). 350 female students were divided on 6 , the results were 58-59 students were collected from each school.

\subsection{Sample criteria}

The inclusion sampling criteria were: Secondary school girls of all grades (1st, 2nd, 3rd), Saudi \& non-Saudi nationalities, enrolled in a governmental school in Riyadh city during the time of the study, willingness to participate in the study, while the exclusion criterion was refusal to participate in this study.

\subsection{Tools of data collection}

Two tools were used for data collection in the current study.

Tool I: The self-administered questionnaire: The questionnaire was designed by the researchers, and it consists of three parts as follows:

Part I: Included participants' sociodemographic data such as, educational level, mother's age, mother's level of education and employment status, menstrual and gynecological history.

Published by Sciedu Press
Part II: Knowledge regarding $\mathrm{RH}$ aspects, which are described as follows:

(1) Domain 1 (Knowledge about puberty and marriage): Female adolescents' knowledge regarding the female reproductive system, puberty in girls, menstrual cycle, and marriage.

(2) Domain 2 (Knowledge about pregnancy and childbirth): This consists of questions about the time of ovulation each month, timing of conception, appropriate age for the first pregnancy, signs of pregnancy, the ideal gap between delivery and the next one, abortion, causes of abortion, and precautions for the prevention of abortion.

(3) Domain 3 (Knowledge about family planning methods for females): This includes family planning methods and the proper way to obtain contraceptives.

(4) Domain 4 (Knowledge about STDs): Knowledge regarding what STDs are, possibility of recovery, and the effect of infection of STD on RH.

(5) Domain 5 (Source of knowledge): This domain comprises fourteen items that address the source of information regarding $\mathrm{RH}$.

Part III: This involved obtaining an insight into the hygiene practices during menstruation. It comprised of 10 items related to menstruation, which included the number of times of changing sanitary pads and the method of disposal, medium used for cleaning, washing the genitalia while showering, number of baths taken during menstruation, activities and exercise during menstruation, foods and drinks that should and should not be taken during menstruation, underwear type used during menstruation.

Tool II: A three point Likert-type scale was developed to assess students' responses to attitude items regarding $\mathrm{RH}$. This scale consist of 8 items that include the adolescents' attitude towards puberty, menstrual cycle, pregnancy and childbirth, family planning methods, STDs, and the use and access of RH services for adolescents.

\subsection{Pilot study}

To assess the clarity, feasibility, and applicability of the tools used in this study for data collection, a pilot study was conducted with $10 \%$ of the predetermined sample size according to the study criteria. The results of the pilot study helped in the necessary modifications of the tools according to the content validity and results of the pilot study. The sample used in the pilot study was excluded from participation in the main study. 


\subsection{Reliability and validity of the instrument}

The content validity of the questionnaire was reviewed by five experts from the same field in order to establish the relevance of the questionnaire items to the study objectives. The experts conducted their review separately. To sustain the self-determination of the reviews, all reviewers were asked to carry out the reviews alone; the reviewers' identities were not revealed to each other aside from the researcher. The results indicate that expert reviews have a significant impact on identifying the issues with the questions. Therefore, some changes were applied based on experts' recommendations. The internal consistency was also measured. Student's answers related to knowledge were scored and calculated. According to the answers, students' responses were evaluated using the model key answer sheet previously prepared by the researchers based on literature review. To score students' knowledge regarding $\mathrm{RH}$, correct and complete answers were scored as 2, while an incorrect wrong answer was scored zero. An attitudinal assessment scale - a three-point Likerttype scale (agree, uncertain, disagree)—was developed to examine students' responses to the items assessing attitude towards RH. It consists of 8 statements to which the students were asked to respond by selecting one of the choices. To score students' attitude towards RH, a score of 3 was given for 'agree', 2 for 'uncertain' and 1 for 'disagree'. Each question was scored, and the maximum possible attitude score was 24 points. The total score ranging from 21-24 indicates a positive attitude towards $\mathrm{RH}$, and a total score less than 12 $(50 \%)$ indicates negative attitude towards $\mathrm{RH}$.

\subsection{Ethical consideration}

Approval from the KSU Nursing College and Ministry of Health were obtained prior to data collection. The participants were provided the data collection tool, which contained the study explanation, its purpose, and the instructions for the participants. The responses were anonymous, and their consent to share the results in the study was obtained. Participation was voluntary, and the participants had the right to withdraw from the study at any time without affecting their rights. All answers were kept confidential and for the purpose of the current study. There was no known harm or conflict to the participants in relation to participation in this study.

\subsection{Data analysis}

After data collection, the data were checked for their quality and completeness. Each questionnaire was coded and scored on the basis of the appropriate scoring method. Data were loaded and analyzed using Statistical Package for Social Science (SPSS) Version 22 (SPSS Inc, IBM). Descriptive statistics were used to describe the sample variables frequen- cies, means, and standard deviations. $p$-value was significant at $<.05$. Chi-squared test was used to examine the distribution of the data, and independent sample $t$-test was used to compare the variables.

\section{RESULTS}

More than half $(52.3 \%)$ of the adolescents' age ranged from 17 to 19 years, while less than half $(43.1 \%)$ were aged 15 to 17 years old. Regarding the student's grades, $31.4 \%$, 42\%, and $26.3 \%$ were in the 1 st, 2 nd, and 3 rd grades, respectively. More than half $(56.3 \%)$ of their mothers had completed compulsory school education, while $28 \%$ completed university education. Regarding the age, about $61.4 \%$ of mothers were aged 35 to 45 years old. The majority of the mothers (79\%) were unemployed.

With respect to knowledge of female adolescents regarding puberty and marriage as shown in Table 1, it is evident that more than half $(54.3 \%)$ of the participants had correct knowledge about the female reproductive organs, while $45.2 \%$ did not have correct knowledge, with no significant statistical differences $(p=.086)$. More than half $(59.4 \%)$ had correct knowledge about puberty signs in girls, while $40.3 \%$ have incorrect knowledge. The differences are highly significant with $p<.000$. Concerning knowledge about menstrual cycle, it was noticed that female adolescents had a high rate of correct answers (92\%) about the cause of menstruation with significant differences $(p<.000)$. Regarding knowledge about marriage, the majority $(88 \%)$ had correct knowledge about the appropriate age for marriage with significant difference $(p<.000)$.

Table 2 shows the distribution of female adolescents in terms of knowledge about pregnancy and childbirth.

Table 3 shows that most of the students $(87.1 \%)$ had correct knowledge about contraceptive pills, and $72 \%$ were knowledgeable about breastfeeding as a method of family planning $(p<.000)$. Knowledge about female sterilization and male sterilization was poor ( $85 \%$ and $79 \%$, respectively) with a significant difference $(p<.000)$.

Table 4 shows the distribution of female adolescents in terms of their knowledge about STDs. For $15 \%$ and $16.4 \%$ of the female adolescents, the sources of knowledge about female reproductive system and STDs were books, newspapers, magazines, school textbooks, Fiqh books, while the source of knowledge about puberty.

Table 5 shows the distribution of female adolescents according to their RH practices during menstruation. Most of female students $(99.4 \%, 93.7 \%, 93.4 \%, 92.9 \%, 87.7 \%, 87.1 \%$, and $85.1 \%$ ) had correct practices with respect to the number 
of times of changing sanitary pads each day, the way of dis- However, more than two-third (68.6\%) had incorrect knowlposing sanitary pads, washing the genitalia while showering, edge about the tools used for cleaning during menstrual cycle, foods and drinks that should not be taken during menstrua- and also the majority (82.6\%) did not practice any activities tion, number of baths during the menstrual cycle, underwear or exercise during menstrual cycle $(p<.000)$.

type used, and towels used during menstruation, respectively.

Table 1. Distribution of female adolescents related to their knowledge about puberty and marriage $(\mathrm{n}=350)$

\begin{tabular}{|c|c|c|c|c|c|}
\hline \multirow{2}{*}{ Items } & \multicolumn{2}{|c|}{ Correct Answers } & \multicolumn{2}{|c|}{ Incorrect Answers } & \multirow{2}{*}{$p$ value } \\
\hline & No. & $\%$ & No. & $\%$ & \\
\hline \multicolumn{6}{|c|}{ Knowledge of female adolescents regarding the female reproductive system } \\
\hline Female reproductive organs & 190 & 54.3 & 158 & 45.2 & .086 \\
\hline \multicolumn{6}{|l|}{ Knowledge about puberty in girls } \\
\hline Puberty signs in girls & 208 & 59.4 & 141 & 40.3 & .000 \\
\hline \multicolumn{6}{|c|}{ Knowledge about menstrual cycle } \\
\hline Cause of menstruation & 321 & 91.7 & 29 & 8.3 & .000 \\
\hline Source of menstrual blood & 244 & 69.7 & 106 & 30.3 & .000 \\
\hline Menstrual blood discharge site & 201 & 57.4 & 149 & 42.6 & .005 \\
\hline \multicolumn{6}{|l|}{ Knowledge about Marriage } \\
\hline Appropriate age for marriage & 307 & 87.7 & 43 & 12.3 & .000 \\
\hline
\end{tabular}

Note. N.B significant at .05.

Table 2. Distribution of Female Adolescents in terms of knowledge about Pregnancy and Childbirth $(\mathrm{n}=350)$

\begin{tabular}{|c|c|c|c|c|c|}
\hline \multirow{2}{*}{ Items } & \multicolumn{2}{|c|}{ Correct Answers } & \multicolumn{2}{|c|}{ Incorrect Answers } & \multirow{2}{*}{$p$ value } \\
\hline & No. & $\%$ & No. & $\%$ & \\
\hline Time of ovulation each month & 41 & 11.7 & 309 & 88.3 & .000 \\
\hline Timing of conception & 5 & 1.4 & 345 & 98.6 & .000 \\
\hline Appropriate age for the first pregnancy & 317 & 90.5 & 33 & 9.5 & .000 \\
\hline Signs of pregnancy & 219 & 62.6 & 131 & 37.4 & .000 \\
\hline Ideal gap between delivery and the next one & 206 & 58.8 & 144 & 41.2 & .001 \\
\hline Meaning of abortion & 24 & 6.9 & 326 & 93.1 & .000 \\
\hline Causes of abortion & 273 & 78 & 77 & 22 & .000 \\
\hline Precautions for the prevention of abortion & 320 & 91.4 & 30 & 8.6 & .000 \\
\hline
\end{tabular}

Table 3. Distribution of Female Adolescents in terms of knowledge about Family planning methods $(n=350)$

\begin{tabular}{|c|c|c|c|c|c|}
\hline \multirow{2}{*}{ Items } & \multicolumn{2}{|c|}{ Correct Answers } & \multicolumn{2}{|c|}{ Incorrect Answers } & \multirow{2}{*}{$p$ value } \\
\hline & No. & $\%$ & No. & $\%$ & \\
\hline \multicolumn{6}{|l|}{ Known family planning methods } \\
\hline Female sterilization (severing the fallopian tubes) & 54 & 15.4 & 296 & 84.6 & .000 \\
\hline Contraceptive pills & 305 & 87.1 & 45 & 12.9 & .000 \\
\hline Intrauterine device (IUD) & 221 & 63.1 & 129 & 36.9 & .000 \\
\hline Breastfeeding & 252 & 72 & 98 & 28 & .000 \\
\hline Hormonal injection & 81 & 23.1 & 269 & 76.9 & .000 \\
\hline Condom & 145 & 41.4 & 205 & 58.6 & .001 \\
\hline Male sterilization & 74 & 21.1 & 276 & 78.9 & .000 \\
\hline Localized methods & 56 & 16 & 294 & 84 & .000 \\
\hline Temperature measurement/evaluation method & 96 & 27.4 & 254 & 72.6 & .000 \\
\hline Isolation (withdrawal) & 81 & 23.1 & 269 & 76.9 & .000 \\
\hline \multicolumn{6}{|l|}{ Obtaining contraceptives } \\
\hline The proper way to obtain contraceptives & 279 & 79.7 & 71 & 20.3 & .000 \\
\hline
\end{tabular}


Table 4. Distribution of Female Adolescents related to knowledge About sexually transmitted diseases $(\mathrm{n}=350)$

\begin{tabular}{|c|c|c|c|c|c|}
\hline \multirow{2}{*}{ Items } & \multicolumn{2}{|c|}{ Correct Answers } & \multicolumn{2}{|c|}{ Incorrect Answers } & \multirow{2}{*}{$p$ value } \\
\hline & No. & $\%$ & No. & $\%$ & \\
\hline \multicolumn{6}{|l|}{ 1. Sexually transmitted diseases are } \\
\hline Gonorrhea & 132 & 37.7 & 218 & 62.3 & .000 \\
\hline Syphilis & 108 & 30.9 & 242 & 69.1 & .000 \\
\hline Chlamydia & 35 & 10.0 & 315 & 90 & .000 \\
\hline Human immunodeficiency virus, HIV/AIDS & 293 & 83.7 & 57 & 16.3 & .000 \\
\hline Genital herpes/ulcer & 130 & 37.1 & 220 & 62.9 & .000 \\
\hline \multicolumn{6}{|c|}{ 2. The possibility of recovery from all sexually transmitted diseases } \\
\hline Recovery from sexually transmitted diseases & 152 & 43.4 & 198 & 56.6 & .014 \\
\hline \multicolumn{6}{|l|}{ 3. Curable sexually transmitted diseases } \\
\hline Curable sexually transmitted diseases & 16 & 4.6 & 334 & 95.4 & .000 \\
\hline \multicolumn{6}{|c|}{ 4. Effect of infection of sexually transmitted diseases on RH } \\
\hline The effect of infection of STD on RH & 162 & 46.3 & 188 & 53.7 & .165 \\
\hline
\end{tabular}

Table 5. Distribution of Female Adolescents in terms of practices regarding RH during menstruation $(n=350)$

\begin{tabular}{|c|c|c|c|c|c|}
\hline \multirow{2}{*}{ Items } & \multicolumn{2}{|c|}{ Correct Answers } & \multicolumn{2}{|c|}{ Incorrect Answers } & \multirow{2}{*}{$p$ value } \\
\hline & No. & $\%$ & No. & $\%$ & \\
\hline Number of times of changing sanitary pads per day & 348 & 99.4 & 2 & 0.6 & .000 \\
\hline Towels used during menstruation & 298 & 85.1 & 52 & 14.9 & .000 \\
\hline Number of baths during the menstruation & 307 & 87.7 & 43 & 12.3 & .000 \\
\hline Genitalia washing & 327 & 93.4 & 23 & 6.6 & .000 \\
\hline Tools used for cleaning during menstruation & 110 & 31.4 & 240 & 68.6 & .000 \\
\hline The method of disposing sanitary pads & 328 & 93.7 & 22 & 6.3 & .000 \\
\hline Activities and exercises during menstruation & 61 & 17.4 & 289 & 82.6 & .000 \\
\hline Foods and drinks that should not be taken during menstruation & 325 & 92.9 & 25 & 7.1 & .000 \\
\hline Foods and drinks that should be taken during menstruation & 154 & 44 & 196 & 56 & .032 \\
\hline Underwear type used during menstrual cycle & 305 & 87.1 & 45 & 12.9 & .000 \\
\hline
\end{tabular}

Table 6 illustrates that the highest positive attitudes $(96.6 \%$ changes and attention to personal hygiene during menstruaand $96.3 \%$ ) were toward education about puberty associated tion, respectively.

Table 6. Distribution of Female Adolescents in terms of their attitude toward RH $(n=350)$

\begin{tabular}{|c|c|c|c|c|c|}
\hline \multirow{2}{*}{ Items } & \multicolumn{2}{|c|}{ Positive Attitude } & \multicolumn{2}{|c|}{ Negative Attitude } & \multirow{2}{*}{$\begin{array}{l}p \\
\text { value }\end{array}$} \\
\hline & No. & $\%$ & No. & $\%$ & \\
\hline $\begin{array}{l}\text { Education about puberty and associated changes is essential for } \\
\text { adolescent girls }\end{array}$ & 317 & 90.6 & 33 & 9.4 & .000 \\
\hline $\begin{array}{l}\text { Attention to personal hygiene during menstruation is essential to avoid } \\
\text { infections and STD }\end{array}$ & 337 & 96.3 & 13 & 3.7 & .000 \\
\hline Pregnancy at young age affects the health of the fetus and the mother & 167 & 47.7 & 183 & 52.3 & .000 \\
\hline $\begin{array}{l}\text { Closed rapprochement of pregnancy and childbirth affects the mother } \\
\text { and fetus }\end{array}$ & 158 & 45.1 & 192 & 54.9 & .000 \\
\hline The use of family planning methods is useful & 230 & 65.7 & 120 & 34.3 & .000 \\
\hline STDs affect the fetus & 258 & 73.7 & 92 & 26.3 & .000 \\
\hline Adolescent girls are in need of RH services & 194 & 55.4 & 156 & 44.6 & .000 \\
\hline Adolescents need to know about the health services for RH & 250 & 71.4 & 100 & 28.6 & .000 \\
\hline
\end{tabular}


Table 7 shows that a positive statistically significant corre- as well as information about pregnancy and childbirth $(p=$ lation was found between educational level of the students $(p=.01)$ and their mother $(p=.001)$ and their knowledge about the female reproductive system. A significant positive correlation was found between students' information about puberty in girls and their educational level $(p=.008)$. Inversed correlation between information about the menstrual cycle and mother's employment status was found $(p=.034)$, .008).

Table 8 illustrates the inversed correlation between adolescents' ages with their practice regarding underwear type used during menstrual cycle ( $p=.043$ ); while a positive correlation was found with their mothers' age $(p=.038)$ and mothers' educational level $(p=.000)$.

Table 7. Correlations between Demographic profile of the mothers and Female adolescents and their Knowledge of RH (n $=350$ )

\begin{tabular}{|c|c|c|c|c|c|c|c|c|}
\hline \multirow[b]{2}{*}{ No. } & \multirow[b]{2}{*}{ Knowledge } & & & \multicolumn{5}{|c|}{ Demographic data } \\
\hline & & & & $\begin{array}{l}\text { Adolescents' } \\
\text { Age }\end{array}$ & $\begin{array}{l}\text { Adolescents' } \\
\text { Educational } \\
\text { level }\end{array}$ & $\begin{array}{l}\text { Mother's } \\
\text { age }\end{array}$ & $\begin{array}{l}\text { Mother's } \\
\text { Educational } \\
\text { level }\end{array}$ & $\begin{array}{l}\text { Mother's } \\
\text { employment } \\
\text { status }\end{array}$ \\
\hline \multirow{4}{*}{1.} & \multirow{4}{*}{$\begin{array}{l}\text { Knowledge of } \\
\text { adolescents regarding } \\
\text { the female } \\
\text { reproductive system }\end{array}$} & Correct & $\mathrm{N}$ & 190 & 190 & 190 & 190 & 190 \\
\hline & & Incorrect & $\mathrm{N}$ & 156 & 156 & 156 & 156 & 156 \\
\hline & & $t$ & & -.809 & $2.580^{* *}$ & 1.568 & $3.287 * *$ & -1.204 \\
\hline & & Sig. & & .419 & .010 & .118 & .001 & .229 \\
\hline \multirow{4}{*}{2.} & \multirow{4}{*}{$\begin{array}{l}\text { Knowledge about } \\
\text { puberty in girls }\end{array}$} & Correct & $\mathrm{N}$ & 207 & 207 & 207 & 207 & 207 \\
\hline & & Incorrect & $\mathrm{N}$ & 141 & 141 & 141 & 141 & 141 \\
\hline & & $t$ & & 1.310 & $2.655 * *$ & -.639 & -.587 & 1.241 \\
\hline & & Sig. & & .191 & .008 & .523 & .557 & .216 \\
\hline \multirow{4}{*}{3.} & \multirow{4}{*}{$\begin{array}{l}\text { Knowledge about the } \\
\text { menstrual cycle }\end{array}$} & Correct & $\mathrm{N}$ & 264 & 264 & 264 & 264 & 264 \\
\hline & & Incorrect & $\mathrm{N}$ & 84 & 84 & 84 & 84 & 84 \\
\hline & & $t$ & & .473 & 1.390 & -1.342 & 1.754 & $-2.125^{*}$ \\
\hline & & Sig. & & .637 & .165 & .180 & .080 & .034 \\
\hline \multirow{4}{*}{4.} & \multirow{4}{*}{$\begin{array}{l}\text { Knowledge about } \\
\text { marriage }\end{array}$} & Correct & $\mathrm{N}$ & 306 & 306 & 306 & 306 & 306 \\
\hline & & Incorrect & $\mathrm{N}$ & 42 & 42 & 42 & 42 & 42 \\
\hline & & $t$ & & .453 & .586 & -.260 & 1.149 & 1.028 \\
\hline & & Sig. & & .651 & .558 & .795 & .251 & .305 \\
\hline \multirow{4}{*}{5.} & \multirow{4}{*}{$\begin{array}{l}\text { Knowledge about } \\
\text { pregnancy and } \\
\text { childbirth }\end{array}$} & Correct & $\mathrm{N}$ & 184 & 184 & 184 & 184 & 184 \\
\hline & & Incorrect & $\mathrm{N}$ & 164 & 164 & 164 & 164 & 164 \\
\hline & & $t$ & & .916 & 1.423 & .267 & -.667 & $-2.648 * *$ \\
\hline & & Sig. & & .360 & .156 & .789 & .506 & .008 \\
\hline \multirow{4}{*}{6.} & \multirow{4}{*}{$\begin{array}{l}\text { Knowledge about } \\
\text { family planning } \\
\text { methods for females }\end{array}$} & Correct & $\mathrm{N}$ & 108 & 108 & 108 & 108 & 108 \\
\hline & & Incorrect & $\mathrm{N}$ & 240 & 240 & 240 & 240 & 240 \\
\hline & & $t$ & & -.361 & -.321 & -.999 & .091 & .205 \\
\hline & & Sig. & & .719 & .749 & .318 & .928 & .838 \\
\hline \multirow{4}{*}{7.} & \multirow{4}{*}{$\begin{array}{l}\text { Knowledge about } \\
\text { STDs }\end{array}$} & Correct & $\mathrm{N}$ & 132 & 132 & 132 & 132 & 132 \\
\hline & & Incorrect & $\mathrm{N}$ & 216 & 216 & 216 & 216 & 216 \\
\hline & & $t$ & & -.655 & .466 & .573 & -.646 & 1.504 \\
\hline & & Sig. & & .513 & .641 & .567 & .519 & .133 \\
\hline \multirow{4}{*}{8.} & \multirow{4}{*}{$\begin{array}{l}\text { Knowledge about } \\
\text { request for treatment }\end{array}$} & Correct & $\mathrm{N}$ & 149 & 149 & 149 & 149 & 149 \\
\hline & & Incorrect & $\mathrm{N}$ & 199 & 199 & 199 & 199 & 199 \\
\hline & & $t$ & & -.145 & .590 & -.879 & -.325 & $-2.140 *$ \\
\hline & & Sig. & & .885 & .556 & .380 & .745 & .033 \\
\hline
\end{tabular}

* Correlation is significant at .05 levels (2-tailed). ${ }^{* *}$ Correlation is significant at .01 levels (2-tailed). 
Table 9 revealed that attitudes toward menstrual cycle had view regarding STDs $(p=.004)$. A statistically positive a statistically positive significant relationship with students' significant relationship was found between point of view age $(p=.015)$ and mother's age $(p=.015)$; while mother's regarding RH services and adolescences' age ( $p=.002)$, ededucation level was inversely correlated with point of view ucational level $(p=.002)$, and mothers' employment status regarding family planning methods $(p=.004)$ and point of $\quad(p=.049)$.

Table 8. Correlations between Demographic profiles of Female Adolescents and their mothers toward RH Practice $(\mathrm{n}=350)$

\begin{tabular}{|c|c|c|c|c|c|c|c|c|}
\hline \multirow[b]{2}{*}{ No. } & \multirow[b]{2}{*}{ Practice } & & & \multicolumn{5}{|c|}{ Demographic data } \\
\hline & & & & $\begin{array}{l}\text { Adolescents' } \\
\text { Age }\end{array}$ & $\begin{array}{l}\text { Adolescents' } \\
\text { Educational } \\
\text { level }\end{array}$ & $\begin{array}{l}\text { Mother's } \\
\text { age }\end{array}$ & $\begin{array}{l}\text { Mother's } \\
\text { Educational } \\
\text { level }\end{array}$ & $\begin{array}{l}\text { Mother's } \\
\text { employment } \\
\text { status }\end{array}$ \\
\hline \multirow{4}{*}{1.} & \multirow{4}{*}{$\begin{array}{l}\text { Number of times } \\
\text { of changing } \\
\text { sanitary pads } \\
\text { each day }\end{array}$} & Correct & $\mathrm{N}$ & 347 & 347 & 347 & 347 & 347 \\
\hline & & Incorrect & $\mathrm{N}$ & 1 & 1 & 1 & 1 & 1 \\
\hline & & $t$ & & -.680 & -1.393 & .429 & -1.092 & -.493 \\
\hline & & Sig. & & .497 & .164 & .668 & .276 & .623 \\
\hline \multirow{4}{*}{2.} & \multirow{4}{*}{$\begin{array}{l}\text { Towels used } \\
\text { during } \\
\text { menstruation }\end{array}$} & Correct & $\mathrm{N}$ & 297 & 297 & 297 & 297 & 297 \\
\hline & & Incorrect & $\mathrm{N}$ & 51 & 51 & 51 & 51 & 51 \\
\hline & & $t$ & & -1.300 & -.555 & -.797 & .220 & .379 \\
\hline & & Sig. & & .194 & .579 & .426 & .826 & .403 \\
\hline \multirow{4}{*}{3.} & \multirow{4}{*}{$\begin{array}{l}\text { Number of baths } \\
\text { during the } \\
\text { menstruation }\end{array}$} & Correct & $\mathrm{N}$ & 306 & 306 & 306 & 306 & 306 \\
\hline & & Incorrect & $\mathrm{N}$ & 42 & 42 & 42 & 42 & 42 \\
\hline & & $t$ & & -1.552 & -1.804 & .483 & 1.385 & -.583 \\
\hline & & Sig. & & .122 & .072 & .630 & .167 & .560 \\
\hline \multirow{4}{*}{4.} & \multirow{4}{*}{$\begin{array}{l}\text { Genitalia } \\
\text { washing }\end{array}$} & Correct & $\mathrm{N}$ & 326 & 326 & 326 & 326 & 326 \\
\hline & & Incorrect & $\mathrm{N}$ & 22 & 22 & 22 & 22 & 22 \\
\hline & & $t$ & & -1.379 & -.348 & .086 & -.570 & -.229 \\
\hline & & Sig. & & .169 & .728 & .932 & .569 & .819 \\
\hline \multirow{4}{*}{5.} & \multirow{4}{*}{$\begin{array}{l}\text { Tools used for } \\
\text { cleaning during } \\
\text { menstruation }\end{array}$} & Correct & $\mathrm{N}$ & 109 & 109 & 109 & 109 & 109 \\
\hline & & Incorrect & $\mathrm{N}$ & 239 & 239 & 239 & 239 & 239 \\
\hline & & $t$ & & -1.086 & -.464 & .172 & .711 & -.870 \\
\hline & & Sig. & & .278 & .643 & .863 & .478 & .385 \\
\hline \multirow{4}{*}{6.} & \multirow{4}{*}{$\begin{array}{l}\text { The way of } \\
\text { disposing } \\
\text { sanitary pads }\end{array}$} & Correct & $\mathrm{N}$ & 327 & 327 & 327 & 327 & 327 \\
\hline & & Incorrect & $\mathrm{N}$ & 21 & 21 & 21 & 21 & 21 \\
\hline & & $t$ & & .310 & .253 & .669 & -.337 & -.123 \\
\hline & & Sig. & & .757 & .801 & .504 & .736 & .902 \\
\hline \multirow{4}{*}{7.} & \multirow{4}{*}{$\begin{array}{l}\text { Activities and } \\
\text { exercise during } \\
\text { menstruation }\end{array}$} & Correct & $\mathrm{N}$ & 62 & 62 & 62 & 62 & 62 \\
\hline & & Incorrect & $\mathrm{N}$ & 286 & 286 & 286 & 286 & 286 \\
\hline & & $t$ & & .542 & .440 & -.556 & -1.121 & .504 \\
\hline & & Sig. & & .588 & .660 & .578 & .263 & .615 \\
\hline \multirow{4}{*}{8.} & \multirow{4}{*}{$\begin{array}{l}\text { Foods and drinks } \\
\text { should not be } \\
\text { taken during } \\
\text { menstruation }\end{array}$} & Correct & $\mathrm{N}$ & 25 & 25 & 25 & 25 & 25 \\
\hline & & Incorrect & $\mathrm{N}$ & 323 & 323 & 323 & 323 & 323 \\
\hline & & $t$ & & -1.166 & -.720 & .903 & 1.515 & -1.002 \\
\hline & & Sig. & & .244 & .472 & .367 & .131 & .317 \\
\hline \multirow{4}{*}{9.} & \multirow{4}{*}{$\begin{array}{l}\text { Foods and drinks } \\
\text { that should be } \\
\text { taken during } \\
\text { menstruation }\end{array}$} & Correct & $\mathrm{N}$ & 179 & 179 & 179 & 179 & 179 \\
\hline & & Incorrect & $\mathrm{N}$ & 169 & 169 & 169 & 169 & 169 \\
\hline & & $t$ & & -.195 & -.880 & -.957 & -.791 & .264 \\
\hline & & Sig. & & .846 & .380 & .339 & .429 & .792 \\
\hline \multirow{4}{*}{10.} & \multirow{4}{*}{$\begin{array}{l}\text { Underwear type } \\
\text { used during } \\
\text { menstruation }\end{array}$} & Correct & $\mathrm{N}$ & 304 & 304 & 304 & 304 & 304 \\
\hline & & Incorrect & $\mathrm{N}$ & 44 & 44 & 44 & 44 & 44 \\
\hline & & $t$ & & $-2.026 *$ & -.722 & $2.080^{*}$ & $.377 * *$ & -.335 \\
\hline & & Sig. & & .043 & .471 & .038 & .000 & .738 \\
\hline
\end{tabular}

* Correlation is significant at .05 levels (2-tailed). ${ }^{* *}$ Correlation is significant at .01 levels (2-tailed). 
Table 9. Correlations between Demographic profile of Female adolescents and their mother regarding RH Attitude $(\mathrm{n}=$ 350)

\begin{tabular}{|c|c|c|c|c|c|c|c|c|}
\hline \multirow[b]{2}{*}{ No. } & \multirow[b]{2}{*}{ Attitude } & & & \multicolumn{5}{|c|}{ Demographic data } \\
\hline & & & & $\begin{array}{l}\text { Adolescents' } \\
\text { Age }\end{array}$ & $\begin{array}{l}\text { Adolescents' } \\
\text { Educational } \\
\text { level }\end{array}$ & $\begin{array}{l}\text { Mother's } \\
\text { age }\end{array}$ & $\begin{array}{l}\text { Mother's } \\
\text { educational } \\
\text { level }\end{array}$ & $\begin{array}{l}\text { Mother's } \\
\text { employment } \\
\text { status }\end{array}$ \\
\hline \multirow{4}{*}{1.} & \multirow{4}{*}{$\begin{array}{l}\text { Attitude towards } \\
\text { puberty }\end{array}$} & Positive & $\mathrm{N}$ & 316 & 316 & 316 & 316 & 316 \\
\hline & & Negative & $\mathrm{N}$ & 32 & 32 & 32 & 32 & 32 \\
\hline & & $t$ & & .159 & -.182 & .867 & -1.180 & 1.622 \\
\hline & & Sig. & & .874 & .855 & .386 & .239 & .106 \\
\hline \multirow{4}{*}{2.} & \multirow{4}{*}{$\begin{array}{l}\text { Attitude toward } \\
\text { menstrual cycle. }\end{array}$} & Positive & $\mathrm{N}$ & 335 & 335 & 335 & 335 & 335 \\
\hline & & Negative & $\mathrm{N}$ & 13 & 13 & 13 & 13 & 13 \\
\hline & & $t$ & & $2.434^{*}$ & .852 & $2.444 *$ & 1.236 & 1.654 \\
\hline & & Sig. & & .015 & .395 & .015 & .217 & .099 \\
\hline \multirow{4}{*}{3.} & \multirow{4}{*}{$\begin{array}{l}\text { Attitude towards } \\
\text { pregnancy and } \\
\text { childbirth }\end{array}$} & Positive & $\mathrm{N}$ & 247 & 247 & 247 & 247 & 247 \\
\hline & & Negative & $\mathrm{N}$ & 101 & 101 & 101 & 101 & 101 \\
\hline & & $t$ & & -1.124 & -.391 & .664 & -1.044 & 1.647 \\
\hline & & Sig. & & .262 & .696 & .507 & .297 & .100 \\
\hline \multirow{4}{*}{4.} & \multirow{4}{*}{$\begin{array}{l}\text { Attitude towards } \\
\text { family planning } \\
\text { methods }\end{array}$} & Positive & $\mathrm{N}$ & 229 & 229 & 229 & 229 & 229 \\
\hline & & Negative & $\mathrm{N}$ & 119 & 119 & 119 & 119 & 119 \\
\hline & & $t$ & & 1.673 & .819 & -1.389 & $-2.925^{* *}$ & .017 \\
\hline & & Sig. & & .095 & .413 & .166 & .004 & .986 \\
\hline \multirow{4}{*}{5.} & \multirow{4}{*}{$\begin{array}{l}\text { Attitude towards } \\
\text { STDs }\end{array}$} & Positive & $\mathrm{N}$ & 257 & 257 & 257 & 257 & 257 \\
\hline & & Negative & $\mathrm{N}$ & 91 & 91 & 91 & 91 & 91 \\
\hline & & $t$ & & 1.153 & 1.941 & .530 & $-2.911^{* *}$ & 1.104 \\
\hline & & Sig. & & .250 & .053 & .596 & .004 & .270 \\
\hline \multirow{4}{*}{6.} & \multirow{4}{*}{$\begin{array}{l}\text { Attitude towards } \\
\text { reproductive } \\
\text { health services }\end{array}$} & Positive & $\mathrm{N}$ & 261 & 261 & 261 & 261 & 261 \\
\hline & & Negative & $\mathrm{N}$ & 87 & 87 & 87 & 87 & 87 \\
\hline & & $t$ & & $3.048^{* *}$ & $3.180 * *$ & .326 & -1.681 & $1.978 *$ \\
\hline & & Sig. & & .002 & .002 & .745 & .094 & .049 \\
\hline
\end{tabular}

* Correlation is significant at .05 levels (2-tailed). ${ }^{* *}$ Correlation is significant at .01 levels (2-tailed).

\section{DisCussion}

The age of female adolescents in the current study ranged from 15 to 19 years. The age of $52.3 \%$ of the participants ranged from 17 to 19 years, while $34.1 \%$ were aged 15 to 17 years, which is similar to the findings reported by Mittal and Goel (2010) and Akhtar et al. (2012), who assessed the knowledge and perception about the RH issues among unmarried adolescent girls aged 15-19 years. More than half of their respondents were aged $18-19$ years $(55 \%) .^{[26,27]}$ In the present study, the majority (88.3\%) of the students females being menstruated between age of 11 to less than 15 years old, and about two-thirds had regular cycles, which coincide with the studies conducted in India by Savanthe et al. (2016) and Kamath et al. (2013). ${ }^{[14,28]}$ In the same context, abdominal pain followed by back pain was found to be the most frequent complaint during menstruation among the students in the present study, which is similar to the results reported by Savanthe et al. ${ }^{[27]}$ Regarding knowledge about puberty and menstruation, the results of the current study revealed that more than half of the female adolescents had correct knowledge about the signs of sexual maturation in females such as breast development, pubic hair development, menstruation, increase in height and weight, which may be due to the information they achieved in courses on religion and biology. This is in line with a study conducted in Baghdad City, which reported that half of the adolescent girls had good awareness about pubertal changes (primary sex characteristics, attaining sexual maturity, onset of menstruation and pubic hair). ${ }^{[29]}$ The present study showed that $91.7 \%$ of female adolescents gave correct answers about the cause of menstruation as a normal sign of growth and puberty, while only $8.3 \%$ girls did not know the cause of menstruation. This finding is similar to the study results of Savanthe et al., who reported that most of the students ( $86 \%$ ) understand that menstruation is normal phenomenon ${ }^{[28]}$ and another finding by Das et al. (2016) in a study conducted among high school girls in Vadodara city, wherein $70 \%$ identified that menstruation is a normal process. However, the findings of another study are consistent with 
the current results as it reported that $70 \%$ of the girls thought that menstruation is an unnatural process. ${ }^{[30]}$

Shatha (2013) reported that adolescents' answers about the site of menstrual blood were correct $(76.0 \%) .{ }^{[29]}$ This coincides with the findings of the present study; $69.7 \%$ of the adolescents had correct knowledge that the source of menstrual blood source is the uterus, while it is inconsistent with the finding of Savanthe et al.'s study (2016). ${ }^{[28]}$ Moreover, Bhattacharjee et al. (2013) reported that approximately one-third of their sample correctly identified the source of menstrual blood $(30 \%){ }^{[31]}$

This study reported that information regarding different aspects of menstruation was obtained from various resources such as mothers, relatives, media (TV or Internet), which is similar to the results found by Dasgupta et al. (2008) in a study conducted in Kolkata. ${ }^{[32]}$ Further, another study carried out in Tirupati by Reddy et al. (2005) found that mothers $(61.2 \%)$ were the primary source of information about menstruation. Therefore, it can be said that mothers are mainly the primary source of information for this important topic. ${ }^{[33]}$ This could be due to good communication between the mothers and daughters as many mothers are being educated nowadays. Female students had inadequate knowledge regarding the time of ovulation per month and the timing of conception. This may be due lack of discussion regarding some RH topics in the school or family. Similar results were found by Parasuraman et al. (2005), ${ }^{[34]}$ Patanwar et al. (2013), and Abiodun et al. (2016). ${ }^{[35,36]}$ In addition, the majority of the girls in the current study had adequate knowledge about the appropriate age for the first pregnancy to be above 20-30 years; this is in agreement with a study by Patanwar et al. (2013) ${ }^{[35]}$ and Lamadah et al. (2015). ${ }^{\text {[37] }}$ Among the respondents of the present study, more than half of adolescent girls stated that the ideal gap between delivery and the next one is more than 2 years. This is consistent with the study done in Ludhiana, which showed that $62 \%$ of the adolescent girls preferred a gap of more than 2 years between the pregnancies. ${ }^{[38,39]}$ The Child Marriage Restraint Act of 1978 raised the legal age for marriage from 15 to 18 years for girls. Awareness regarding the appropriate age for marriage was very high in the current study. These results are similar to a study done by Fatemeh et al. (2015). ${ }^{[40]}$

Regarding the knowledge about family planning methods, oral contraceptive pills (OCP) was the most known contraceptive method. This is in agreement with the findings of the study done in Ethiopia (2014) and Nigeria (2016). It was not surprising that $72 \%$ of the female adolescents gave correct answers regarding breastfeeding as a family planning method followed by intrauterine devices (IUD), which may be due to the information received from their mothers and relatives as well as school lessons. On the other hand, longterm contraceptive methods were relatively unknown among the students in the current study similar to other adolescents in the previous studies. ${ }^{[36-41]}$

Knowledge about female sterilization and male sterilization was poor, which is somewhat similar to a study done by Patanwar et al. (2013) who reported that only $14.1 \%$ of adolescents had knowledge about female sterilization, and $7 \%$ had knowledge about male sterilization. ${ }^{[35]}$ This result contradicts that of Gollakota et al.'s study (2015), who reported higher knowledge among female adolescents regarding female and male sterilization in their study. ${ }^{[42]}$

HIV/AIDS was the most known STD among the adolescents of the current study, and this is expected due to a current worldwide pandemic of the disease. This is consistent with the studies of Abiodun et al. (2016), Patanwar et al. (2013), and Gollakota et al. (2015). ${ }^{[35-42]}$ The adolscents in the current study were aware of STDs like Syphilis, Gonorrhea, and ulcer in the genital area. Although chlamydial infections are the major causes of pelvic inflammatory diseases, tubal occlusions, and infertility, only $10 \%$ of the students in the current study were aware of it. This is closely consistent with Gollakota et al.'s (2015) results. ${ }^{[42]}$ The main sources of information regarding STDs for the students in the current study were school textbooks, Internet, followed by the mother and TV. They learned about the topics in the courses discussed in the school classes as it was the major source of knowledge regarding STDs. On the other hand, mothers, relatives, and the Internet were reported as the least common source of STD information. This is may be due to the society in the Middle East where parents hesitate to discuss some important RH issues with their daughter and even sons. These findings were similar to the findings of a study done in Nepal and Bangladesh. ${ }^{[43]}$ Regarding the cure for STDs, the majority of the students in the current study had incorrect knowledge about curable diseases; this is consistent with the studies of Patanwar et al. (2013)., ${ }^{[35]}$ and Masood et al. (2015), which reported wrong perception among their samples. ${ }^{[44]}$ Most of the female adolescents in the present study had overall incorrect knowledge about RH. The findings of the current study are similar to those of Lamadah et al.'s study (2015), which reported low overall knowledge in their sample. ${ }^{[37]}$ However, the results of the current study contradict with that of Farih et al. (2014) who reported that half of their study sample had a good level of knowledge. ${ }^{[23]}$

The current study revealed that the majority of girls who followed correct hygienic practices during menstruation with 
respect to the type of towels used were those who used sanitary pads $(85.1 \%)$. This is consistent with the findings of Bhattacherjee et al. in West Bengal, India, who reported about $71.3 \%$ of their study subjects used sanitary pads as absorbents. ${ }^{[31]}$ The common use of pads may be a result of high availability and increased awareness from television regarding availability and use of sanitary napkins. Moreover, a high percentage $(99.4 \%)$ of girls correctly answered the question on frequency of changing sanitary pads per day. In contrast, a study by Mudey et al. reported that cleanliness of external genitalia was unsatisfactory. ${ }^{[15]}$

The present study showed that $93.7 \%$ girls followed correct practices on methods of disposal of used sanitary pads including using the correct place for waste disposal. The same results were reported by other studies. ${ }^{[28]}$ Incorrect hygiene practices were common; $68.6 \%$ of female adolescents used soap or shampoo for cleaning the external genitalia in the current study. This is consistent with a study by Sreedhar et al. who reported soap and water were the most common materials used by girls $(82.2 \%)$ for cleaning the external genitalia. ${ }^{[45]}$ There are different beliefs and taboos related to restricted movement and feeding patterns during menstruation in different cultures, which guide the menstrual practices of female adolescent. Bathing during menstruation is traditionally forbidden in rural cultures in Egypt and Pakistan. ${ }^{[46,47]}$ Aktar et al. and Mohite et al. ${ }^{[16,17]}$ reported that almost all girls practiced similar personal hygiene during menstruation. However, in the present study, a high percentage of female students reported that they take a shower every day $(87.7 \%)$ or after $1-2$ days $(93.4 \%)$ during menstruation and that washing the genitalia while showering is recommended, which is in contrast with Bhattacherjee et al.'s study in West Bengal, which observed that less than one third of girls practiced good personal hygiene. Mudey et al. reported that only $34.33 \%$ of the girls cleaned their genitalia. $^{[15-31,48-51]}$

Activities and exercise restrictions were varied among the girls in the present study as the majority of them did not attend schools or perform routine household work or participate in family events; they preferred to sleep and rest. This is possibly due to different rituals in the community; the girls followed the practices of their mothers or other elderly women in the family. These findings were consistent with other previous studies on adolescents in similar communities. ${ }^{[45-47,52]}$ The majority of female adolescents in the present study followed correct $\mathrm{RH}$ practices, which is consistent with the study by Gothankar et al. in India. ${ }^{[53]}$ In regard to female adolescents' attitude toward aspects of $\mathrm{RH}$, the majority had positive attitude regarding the importance of puberty education, personal hygiene during menstruation,

Published by Sciedu Press usefulness of family planning methods for female RH, STD risk for the fetus, and the need for RH services to be accessible for adolescents, which is consistent with the study results of Lamadah et al. and Tegegn et al. ${ }^{[19-37,48-51]}$ However, these results contradict those of Fetohy who found that the mean score of students' attitudes toward personal hygiene during menstruation was low among adolescents. ${ }^{[5]}$ The participants had negative attitudes toward teenage pregnancy and close frequency of pregnancies that may threaten the mother's and fetal health, which contradicts the results of Lamadah et al. ${ }^{[37]}$ This may be a result of social traditions that prefer pregnancy at a young age and gestations that are not spaced apart.

\section{Conclusion}

In the light of the current study findings, it is concluded that RH knowledge among the adolescents was unsatisfactory based on the correct answers $(33.7 \%)$, while more than two-thirds $(66.3 \%)$ of the participants had incorrect knowledge. The present study revealed that the majority of the adolescents did not have correct knowledge about puberty, pregnancy and childbirth, family planning methods, STDs, and request for treatment. On the other hand, adolescents had correct knowledge about the appropriate age for marriage and HIV than other STDs. Regarding the hygiene practices, most students had correct practices with respect to menstruation, while a few had incorrect practices. The majority had positive attitudes regarding $\mathrm{RH}$, while a few had negative attitudes.

\section{Recommendations}

(1) Health care professionals and nurses must be trained properly to provide $\mathrm{RH}$ services at schools and primary health care settings.

(2) Primary health care practitioners should be wellprepared to provide education about RH to increase parental involvement to improve care quality for adolescents.

(3) Safe RH can be achieved by incorporating family education, which focuses on learning about living, family, and social relationships through well prepared nurses who can provide education at schools for parents and teachers.

(4) Future nursing research should focus on RH. A similar study can be conducted on the same topic with a broader perspective by evaluating a few schools from each region in the $\mathrm{KSA}$.

\section{Conflicts of InTEREST Disclosure}

The authors declare that there is no conflict of interest. 


\section{REFERENCES}

[1] World Health Organization (WHO). Adolescent development. 2017 [cited 2017]; Available from: http://www. who.int/maternal_c hild_adolescent/topics/adolescence/dev/en/

[2] Khanal P. Adolescents Knowledge and Perception of Sexual and Reproductive Health and Services-A study from Nepal [Master's thesis]: University of Eastern Finland, Kuopio; 2016 [cited 2017 July 12].

[3] Dube S, Sharma K. Knowledge, Attitude and Practice Regarding Reproductive Health among Urban and Rural Girls: A Comparative Study. Ethno-Med. 2012; 6(2): 85-94. https : //doi .org/10.108 $0 / 09735070.2012 .11886424$

[4] Spielberg LA. Introduction to Reproductive Health \& Safe Motherhood. Global Health Education Consortium and collaborating partners [presentation] Dartmouth Medical School. December 2007.

[5] Fetohy EM. Impact of a Health Education Program for Secondary School Saudi Girls About Menstruation at Riyadh City. J Egypt Public Health Assoc. 2007; 82(1-2): 105-26. PMid:18217327

[6] Rashad H, Osman M, Fahimi FR. Marriage In The Arab World.Washington: Population Reference Bureau; 2005. Available from: http://www.prb.org/pdf05/marriageinarabwo rld_eng.pdf

[7] Hunshal SC, Pujar LL, Netravati HS. Reproductive health knowledge among rural adolescent girls. Karnataka Journal of Agricultural Sciences. 2010; 23(3): 544-46. PMid:26591669

[8] Dangat CM, Njau B. Knowledge, attitudes and practices on family planning services among adolescents in secondary schools in Hai District, northern Tanzania. Tanzan J Health Res. 2013 Jan; 15(1): 19-25.

[9] Albezrah NA. Use of modern family planning methods among Saudi women in Taif, KSA. Int J Reprod Contracept Obstet Gynecol. 2015; 4(4): 990-994. https://doi.org/10.18203/2320-1770.ijrc og20150412

[10] Fageeh WM. Awareness of Sexually Transmitted Diseases among Adolescents in Saudi Arabia. Med Sci. 2008; 15(1): 77-90.

[11] Al-Malki BM. Knowledge and awareness of sexually transmitted diseases among male university students in Taif, Saudi Arabia. Int J Med Sci Public Health. 2014; 3(3): 342-48. https ://doi .org/10 .5455/ijmsph. 2014.070120141

[12] DeJong J, Shepard B, Roudi-Fahimi F, et al. Young People's Sexual and Reproductive Health in the Middle East and North Africa. Reprod Health. Population Reference Bureau. 2007; 14(78): 8.

[13] Alquaiz AM, Almuneef MA, Minhas HR. Knowledge, attitudes, and resources of sex education among female adolescents in public and private schools in Central Saudi Arabia. Saudi Med J. 2012; 33(9): 1001-9. PMid:22964813

[14] Kamath R, Ghosh D, Lena A, et al. A study on knowledge and practices regarding menstrual hygiene among rural and urban adolescent girls in Udupi Taluk, Manipal, India. Global Journal of Medicine and Public Health. 2013; 2(4): 1-9.

[15] Mudey AB, Kesharwani N, Mudey GA, et al. A cross-sectional study on the awareness regarding safe and hygienic practices amongst school going adolescent girls in the rural areas of Wardha district. Glob J Health Sci. 2010; 2(2): 225-31.

[16] Mohite RV, Mohite VR. Menstrual hygiene practices among slum adolescent girls. Int J Community Med Public Health. 2016; 3(7): 1729-34.

[17] Aktar B, Sarker M, Jenkins A. Exploring Adolescent Reproductive Health Knowledge, Perceptions, and Behavior, Among Students of Non-Government Secondary Schools Supported by BRAC Mentoring Program in Rural Bangladesh. Journal of Asian Midwives. 2014; 1(1): 17-33.
[18] Al-Quaiz AM, Kazi A, Muneef MA. Determinants of sexual health knowledge in adolescent girls in schools of Riyadh-Saudi Arabia: a cross sectional study. BMC Womens Health. 2013; 13: 19. Available from: http://www. biomedcentral.com/content/pd f/1472-6874-13-19.pdf PMid:23587104 https://doi.org/ 10.1186/1472-6874-13-19

[19] Tegegn A, Yazachew M, Gelaw Y. Reproductive Health Knowledge and Attitude among Adolescents: A communitybased study in Jimma Town, Southwest Ethiopia. Ethiop J Health Dev. 2016; 22(3): 143-151. Available from: http: //www . academia.edu/5272235/Reproductive_Heal th_Knowledge_and_Attitude_among_Adolescents_A_comm unity_based_study_in_Jimma_Town_Southwest_Ethiopia

[20] Saudi Arabia Birth Rates. 2014. Available from: http://www.ge oba.se/country $\cdot$ php?cc=SA

[21] UNICEF. Saudia Arabia Statistic. 2013. Available from: http://www.unicef .org/infobycountry/saudiarabia_s tatistics.html\#12

[22] Ojong I, Akpan M, Alasia MO, et al. A comparative study on reproductive health awareness among Urban and Rural Secondary School Students in Cross River State, Nigeria. J Res Nurs Midwifery. 2014 Jan; 3(1): 21-5. Available from: http://www.interesjournals .org/full-articles/a-com parative-study-on-reproductive-health-awareness-a mong-urban-and-rural-secondary-school-students-i n-cross-river-state-nigeria.pdf?view=inline

[23] Farih M, Khan K, Freeth D, et al. Protocol study: sexual and reproductive health knowledge, information-seeking behaviour and attitudes among Saudi women: a questionnaire survey of university students. Reprod Health. 2014; 11(34): 1-5. PMid:24383405

[24] Akhter S. Knowledge, attitudes and practices on reproductive health and rights of urban and rural women in Bangladesh. 2007; 12(3).

[25] Polit DF, Beck CT. Nursing Research: Generating and Assessing Evidence for Nursing Practice. 8th ed. Philadelphia: Lippincott; 2007.

[26] Mittal K, Goel MK. Knowledge Regarding Reproductive Health among Urban Adolescent Girls of Haryana. Indian J Community Med. 2010; 35(4): 529-530. https://doi.org/10.4103/0970 $-0218.74374$

[27] Akther N, Begum N, Chowdhury S, et al. Knowledge on reproductive health issues among the unmarried adolescent girls. J Family Reprod Health. 2012; 6(4): 169-176.

[28] Savanthe AM, Nanjundappa VH. Menstruation: A cross-sectional study on knowledge, belief, and practices among adolescent girls of junior colleges, Kuppam, Andhra Pradesh. Int J Med Sci Public Health. 2016; 5(01): 22-7. https://doi.org/10.5455/ijmsph .2016 .100620157

[29] Ali SAM. Adolescent Girls' Awareness towards Reproductive Health in Baghdad City. Iraqi National Journal of Nursing Specialties. 2013; 26(2): 9-15

[30] Das B, Desai GJ. KAP study of reproductive health and sexually transmitted diseases among high school girls of Vadodara city. Int $\mathbf{J}$ Med Sci Public Health. 2016; 5(3): 412-5. https ://doi .org/10 .5455/ijmsph.2016.2507201569

[31] Bhattacherjee S, Ray K, Biswas R, et al. Menstruation: Experiences of Adolescent Slum Dwelling Girls of Siliguri City, West Bengal, India. Journal of Basic and Clinical Reproductive Sciences. 2013 Jul 1; 2(2): 85-91. https://doi.org/10.4103/2278-960X.118646

[32] Dasgupta A, Sarkar M. Menstrual hygiene: How hygienic is the adolescent girl? Indian J Community Med. 2008; 33(2): 77-80. PMid:19967028 https ://doi.org/10.4103/0970-0218.4087 
[33] Reddy PJ, Usha Rani D, Reddy GB, et al. Reproductive health constraints of adolescent school girls. Indian J Soc Work. 2005; 66(4).

[34] Parasuraman S, Kishor S, Singh SK, et al. A profile of youth in India. National Family Health Survey (NFHS-3). 2005.

[35] Patanwar P, Sharma KK. Awareness of reproductive health among the kurmi adolescent girls of Raipur city, Chhattisgarh, India. International Journal of Research in Health Sciences. 2013; 1(13): 127.

[36] Abiodun O, Olu-Abiodun O, Ani F, et al. Sexual and Reproductive Health Knowledge and Service Utilization among Inschool Rural Adolescents in Nigeria. J AIDS Clin Res. 2016; 7(6): 1-8.

[37] Lamadah SM, Mohamed HAE-A, El-Khedr SM. Knowledge, attitude and practices of adolescent females regarding reproductive health at Makkah al Mukaramah. Life Science Journal. 2015; 12(3): 146-58.

[38] Aarthi G, Premarajan KC, Subitha L. Knowledge and Attitude Regarding Reproductive Health Issues and Family Formation Among Adolescent Girls of Puducherry. Online J Health Allied Scs. 2014; 13(4): 1

[39] Benjamin AI, Panda P, Singh S, et al. Knowledge \& Attitude of Senior Secondary School Students of Ludhiana Regarding Population Control \& Contraception. Ind J Comm Med. 2001; 26(4): 10-12.

[40] Bazarganipour F, Foroozanfard F, Taghavi SA, et al. Evaluation of Female Youth Educational Needs about Reproductive Health in NonMedical Students in the City of Qom. J Family Reprod Health. 2013 June; 7(2).

[41] Abajobir A, Seme A. Reproductive health knowledge and services utilization among rural adolescents in east Gojjam zone, Ethiopia: a communitybased cross-sectional study. BMC Health Services Research. 2014; 14(1): 138. PMid:24678725 https://doi.org/10 .1186/1472-6963-14-138

[42] Gollakota S, Mylavarapu SR, Padmavathi K. A Study of Awareness of Reproductive Health among College Students of Visakhapatnam. IOSR Journal of Dental and Medical Sciences. 2015; 14(2): 54-9.
[43] Kabir H, Saha NC, Gazi R. Female unmarried adolescents' knowledge on selected reproductive health issues in two low performing areas of Bangladesh: an evaluation study. BMC Public Health. 2015; 15(1262): 1-9. PMid:25563658

[44] Masood A, Dwivedi S, Tiwary N. Exploring Adolescent Girls Health: A CrossSectional Study. Indian J Appl Res. 2015; 5(3): 37-40.

[45] Sreedhar M, Syed A. Practices of Menstrual hygiene among urban adolescent girls of Hyderabad. Indian Journal of Basic and Applied Medical Research. 2014; 4(1): 478-86.

[46] EL Gilany A, Badwi K, El Fedawy S. Menstrual hygiene among adolescent school girls in Mansoura, Egypt. Reprod Health Matters. 2005; 13(26): 147-52. https://doi.org/10.1016/S0968-808 0 (05) 26191-8

[47] Ali T, Ali P, Waheed $\mathrm{H}$, et al. Understanding of puberty and related health problems among female adolescents in Karachi, Pakistan. J Pak Med Assoc. 2006; 68-72. Available from: http://www . jpma .org.pk/full_article_text.php?article_id=594

[48] Reproductive Health Bio Med Central. 2016. Available from: http: //www.reproductive-health-journal.com/about

[49] Wikipedia; Knowledge. Available from: http://en.wikipedia.o $\mathrm{rg} /$ wiki/Knowledge

[50] Human Behavior. [cited 2016]; Available from: http://www. busi nessdictionary.com/definition/human-behavior.html

[51] Attitude. [cited 2016]; Available from: http://www.businessdi ctionary.com/definition/attitude.html

[52] Ade A, Patil R. Menstrual Hygiene and Practices of Rural Adolescent Girls of Raichur. Int J Biol Med Res. 2013; 4(2): 3014-3017.

[53] Gothankar JS, Patil RS, Plkar SH. Knowledge and practices related to reproductive health amongst adolescent girls. Medical Journal of Dr. D. Y. Patil University. 2015; 8(6): 719-23. https: //doi.org/10.4103/0975-2870.169882 